\title{
MORBIDITY AND SURVIVAL IN ADVANCED AIDS IN RIO DE JANEIRO, BRAZIL
}

\author{
Ângela J. GADELHA(1), Náurea ACCACIO(2), Regina L.B. COSTA(2), Maria Clara GALHARDO(2), Maria Regina COTRIM(2), Rogério V. DE SOUZA(2), \\ Mariza MORGADO(3), Keyla MARZOCHI(2), Maria Cristina LOURENÇO(2) \& Valeria C. ROLLA(2)
}

\begin{abstract}
SUMMARY
Opportunistic diseases (OD) are the most common cause of death in AIDS patients. To access the incidence of OD and survival in advanced immunodeficiency, we included 79 patients with AIDS treated at Hospital Evandro Chagas (FIOCRUZ) from September 1997 to December 1999 with at least one CD4 count $\leq 100$ cells $/ \mathrm{mm}^{3}$. The incidence of OD was analyzed by Poisson's regression, and survival by Kaplan Meier and Cox analysis, considering a retrospective (before CD4 $\leq 100 \mathrm{cells} / \mathrm{mm}^{3}$ ) and a prospective (after CD4 $\leq 100$ cells $/ \mathrm{mm}^{3}$ ) period, and controlling for demographic, clinical and laboratory characteristics. The confidence interval estipulated was $95 \%$.

Mean follow-up period was 733 days $(\mathrm{CI}=683-782)$. During the study $9(11.4 \%)$ patients died. Survival from AIDS diagnosis was a mean of 2589 days $(C I=2363-2816)$ and from the date of the CD4 count CD4 $\leq 100$ cells $/ \mathrm{mm}^{3}$ was a mean of $1376(C I=1181$ 1572 ) days. Incidence of OD was $0.51 \mathrm{pp} / \mathrm{y}$ before CD $4 \leq 100$ cells $/ \mathrm{mm}^{3}$ and $0.29 \mathrm{pp} / \mathrm{y}$ after CD $4 \leq 100$ cells $/ \mathrm{mm}^{3}$. A lower number of ODs before CD4 $<100$ cells $/ \mathrm{mm}^{3}$ was associated with lower incidence rates after CD4 $\leq 100 \mathrm{cells} / \mathrm{mm}^{3}$. AIDS diagnosis based on $\mathrm{CD}^{+}$counts $\leq 200$ cells $/ \mathrm{mm}^{3}$ was associated with lower incidence rates after CD4 $\leq 100$ cells $/ \mathrm{mm}^{3}$. Baseline CD4 counts above 50 cells $/ \mathrm{mm}^{3}(\mathrm{HR}=0.13)$ and restoration of baseline $\mathrm{CD} 4^{+}$counts above $100 \mathrm{cells} / \mathrm{mm}^{3}(\mathrm{HR}=0.16)$ were associated with a lower risk of death. Controling both variables, only restoration of baseline counts was statistically significant $(\mathrm{HR}=0.22, \mathrm{p}=0.04)$.
\end{abstract}

We found a very low incidence of OD and long survival after CD4 $<100$ cells $/ \mathrm{mm}^{3}$. Survival was significantly associated with restoration of baseline CD4 counts above 100 cells $/ \mathrm{mm}^{3}$.

KEYWORDS: AIDS; Morbidity; CD4 counts; Survival.

\section{INTRODUCTION}

The introduction of highly active antiretroviral treatment (HAART) has lowered incidence of opportunistic diseases (ODs) ${ }^{2}$, prolonged survival $^{3,23}$ and reduced AIDS-related hospital admissions ${ }^{21}$. HAART has also had a beneficial effect on individuals with advanced immunosuppression ${ }^{3}$. Little has been done, however, to explore the effects of reconstituting $\mathrm{CD}^{+}$cells on OD incidence, especially among patients at an advanced stage of immunodeficiency ${ }^{16}$.

Evaluation of the effect of universal distribution of anti-retrovirals free-of-charge in São Paulo revealed a 50\% reduction in AIDS-related hospital admission and mortality rates ${ }^{18}$. However, the incidence of AIDSrelated events and the factors that may influence survival following this measure have yet to be evaluated in Brazil.

\section{OBJECTIVES}

To identify the factors associated with morbidity and survival in
AIDS patients treated with HAART at an advanced stage of immunodeficiency, as compared with before CD4 T cell counts dropped below 100 cells $/ \mathrm{mm}^{3}$.

\section{PATIENTS AND METHODS}

We conducted a bidirectional cohort study at the Evandro Chagas Hospital Research Centre (Centro de Pesquisa Hospital Evandro Chagas, CPqHEC) of the Oswaldo Cruz Foundation (FIOCRUZ), Rio de Janeiro, from September 1, 1997 to December 7, 1999. The CPqHEC is an institution that specializes in treating adults with HIV/AIDS or other infectious diseases, and offers reference on clinical and laboratory services.

Inclusion criteria: adult patients with at least an absolute $\mathrm{CD}^{+}$ lymphocyte count of $\leq 100$ cells $/ \mathrm{mm}^{3}$ in peripheral blood.

Exclusion criteria: individuals monitored for less than 90 days at the end of the study were excluded.

The program PAPES II / Fiocruz supported this work.

(1) Escola Nacional de Saúde Pública (ENSP), FIOCRUZ, Rio de Janeiro, RJ, Brazil

(2) Centro de Pesquisa Hospital Evandro Chagas (CPqHEC), FIOCRUZ, Rio de Janeiro, RJ, Brazil

(3) Laboratorio de Imunologia em HIV/AIDS, Instituto Oswaldo Cruz (IOC), FIOCRUZ, Rio de Janeiro, RJ, Brazil

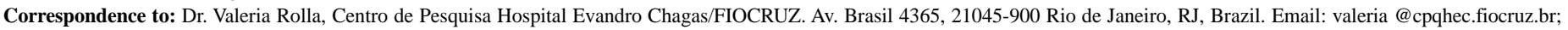
rolla@unisys.com.br 
GADELHA, A.J.; ACCACIO, N.; COSTA, R.L.B.; GALHARDO, M.C.; COTRIM, M.R.; DE SOUZA, R.V.; MORGADO, M.; MARZOCHI, K.; LOURENÇO, M.C. \& ROLLA, V.C. Morbidity and survival in advanced AIDS in Rio de Janeiro, Brazil. Rev. Inst. Med. trop. S. Paulo, 44(4):179-186, 2002.

Criterion for defining AIDS and related ODs: the CDC 1993 criterion was adopted ${ }^{4}$. This study however, did not take account of bacterial pneumonias due to the large number of presumptive diagnoses without bacteriological confirmation.

Data gathering: An initial interview was held to obtain retrospective data on diagnoses of AIDS-indicator diseases, as well as prior antiretroviral treatment. Whenever necessary, this information was complemented by consulting medical records. The monthly prospective evaluation recorded diagnoses of AIDS-related ODs, the antiretroviral treatment used and laboratory data such as plasma HIV1-RNA load and $\mathrm{CD} 4^{+}$cell count, which were repeated every four months.

$\mathrm{CD}^{+} \mathrm{T}$ cells were counted by flow cytometry (Epics XL, Coulter Co, FL, USA), using TriTEST CD4 FITC/ CD8 PE/CD3 PerCP monoclonal antibodies (BD Immunocytometry Systems, SJ, CA, USA). Viral load was measured by NucliSens HIV-1 QT (NASBA Diagnostics, Organon Teknika, Holland) in plasma samples. Both exams were assured by the National Network for CD4 and Viral Load Evaluation, from the National Coordination of Sexual Transmitted Diseases and AIDS, Brazilian Ministry of Health.

Statistical analysis: this contemplated two periods: a prospective period, measured in days, from inclusion in the study (date of the first CD4 count below $100 \mathrm{cell} / \mathrm{mm}^{3}$ ) through to completion of the project, death of the patient or loss of follow-up; and a retrospective period from the AIDS diagnosis through to the $\mathrm{CD}^{+}$cell count of inclusion. OD incidence was analyzed by Poisson regression, and survival by the Kaplan Meier method. The risks associated with the variables were evaluated by Cox regression.

Models were constructed and tested for the incidence of OD (Poisson regression) and survival (Cox proportional harzard model) considering the folowing characteristics: gender, age, the AIDS-defining criterion (OD or CD4 counts $\leq 200$ cells $/ \mathrm{mm}^{3}$ ), start of antiretroviral treatment with monotherapy double therapy or HAART, aggregate number of ODs up to inclusion in the study, $\mathrm{CD} 4^{+}$cell count at the moment of inclusion $\left(\leq 50\right.$, or $>50 /<100$ cells $\left./ \mathrm{mm}^{3}\right)$, restoration of baseline CD4 $4^{+}$cell count (at the 100 and 200 cells $/ \mathrm{mm}^{3}$ cutoffs) and plasma virus loads over time ( $<10,000,<30,000$ and $<100,000$ copies $/ \mathrm{ml})$. A 95\% confidence interval (CI) was stipulated.

Some OD were grouped by relative frequencies and the criterion of severity associated with the diagnosis ${ }^{13,25}$ into: Group 1 - tuberculosis; Group 2 - neurotoxoplasmosis, PCP, Isosporiasis, Cryptosporidiasis and Kaposi's sarcoma; Group 3 - DMAC or Cytomegalovirosis and Group 4 - Candidiasis of the esophagus, Cryptococcosis and Histoplasmosis.

The softwares used for analysis were SPSS 8.0 for Windows ${ }^{22}$ and EGRET $^{28}$.

\section{RESULTS}

Characteristics of the Cohort: The study included 79 individuals. Mean age at AIDS diagnosis was 37.9 years $(\mathrm{SD}= \pm 9.19)$, and median 38 years; age on entry to the study was 39.9 years $(\mathrm{SD}= \pm 9.25)$, and the median 40 years. Of the patients, $57(72 \%)$ were male and $22(28 \%)$ female. Of the 79 individuals monitored, 9 (11.4\%) died from AIDS- related causes. The remaining patients were censored: 66 on completion of the study, 3 for lost follow-up and one for a road accident.

All patients in our study were treated with antiretrovirals. In the retrospective period, $43(67 \%)$ patients had initiated antiretroviral treatment with one drug (monotherapy) and in 21 (33\%) of them the initial treatment was the association of two drugs. The drugs available by the Ministry of Health program were nucleoside reverse transcriptase inhibitors (NRTI), zidovudine (AZT), didanosine (ddI), dideoxycytidine $(\mathrm{ddC})$, and lamivudine (3TC). Initial regimens were: AZT in 40 patients (50.6\%), ddI in $3(3.8 \%)$, double combination with AZT and ddI in 18 patients $(22.8 \%)$, AZT and 3 TC in 2 patients $(2.5 \%)$ and AZT and ddC in one patient $(1.3 \%)$.

During the prospective period, 15 naïve patients were included (19\% of the entire cohort). The treatments available at that time were nucleoside reverse transcriptase inhibitors (NRTI), zidovudine, didanosine, dideoxycytidine, lamivudine and stavudine, in addiction to the protease inhibitors (PI) saquinavir, ritonavir, indinavir and nelfinavir. They initiated their treatments with at least a triple combination as follows: AZT and ddI plus ritonavir in one case (1.3\%), saquinavir in 2 cases $(2.6 \%)$, indinavir in 3 cases $(3.9 \%)$ and nelfinavir in 3 cases $(3.9 \%)$. 3TC and estavudine added to indinavir in one $(1.3 \%)$ case, nelfinavir in $1(1.3 \%)$ case and ritonavir-saquinavir in one $(1.3 \%)$ case. AZT and 3TC plus indinavir in 2 cases $(2.6 \%)$, ritonavir in one case $(1.3 \%)$ and ritonavir-saquinavir in one $(1.3 \%)$ case. The treatment regimens followed varied according to the clinical indication (respecting Brazilian's Guidelines), and a triple therapy was used in almost all patients except in cases requiring rifampicin ( $\mathrm{n}=$ 6), where the PI was suspended for the 6 months of tuberculosis treatment. Nevirapin a non nucleoside reverse transcriptase inhibitor (NNRT) became available during the prospective period.

Incidence of opportunistic diseases: The overall OD rate for the entire period (from AIDS diagnosis to the end of the study) was 0.39 (CI $=0.31-0.47)$ per person per year $(\mathrm{pp} / \mathrm{y})$. A total of 97 ODs occurred, 56 in the retrospective (before CD4 counts $\leq 100$ cells $/ \mathrm{mm}^{3}$ ) period and 41 in the prospective (after CD4 counts $\leq 100$ cells $/ \mathrm{mm}^{3}$ ) period. Of the 79 patients, $26(32.9 \%)$ never suffered from OD at any time during the natural history of HIV.

PROSPECTIVE PERIOD (after CD4 counts $\leq 100$ cells $/ \mathrm{mm}^{3}$ ): The incidence rate of OD in the prospective period was 0.29 per person per year $(\mathrm{CI}=0.21-0.39)$.

We analysed the incidence rates by frequency of aggregate ODs prior to inclusion in the study (Table 1). OD incidence was thus significantly higher $(\mathrm{p}=0.05)$ among those individuals with an aggregate of more than 2 ODs. We also observed that the incidence rate among the patients with tuberculosis $(0.55 \mathrm{pp} / \mathrm{year})$ was nearly twice as high as for those who did not have tuberculosis $(0.23 \mathrm{pp} /$ year $)$.

Almost surprisingly, start-up of antiretroviral treatment with triple combinations with PIs ( $0.54 \mathrm{pp} / \mathrm{year})$ figures as a factor associated with a significant $(\mathrm{p}=0.05)$ greater morbidity in this period in comparison with monotherapic regimens $(0.25 \mathrm{pp} /$ year, Table 1$)$.

Incidence rates were controlled for other variables for which the results, although without statistical significance, are given in Table 2. 
Table 1

Incidence (Poisson regression) of opportunistic diseases (OD) according to demographic, clinical and laboratory characteristics in advanced immunodeficiency - Significant variables for the prospective (after CD4 counts dropped $<100$ cells $/ \mathrm{mm}^{3}$ ) period

\begin{tabular}{|c|c|c|c|c|c|}
\hline Variable & Category & $\mathrm{N}$ & $\begin{array}{l}\text { Incidence of } \\
\text { OD pp/year }\end{array}$ & CI & $\begin{array}{c}\mathrm{P} \\
\text { value }\end{array}$ \\
\hline $\begin{array}{l}\text { Aggregate number of } \\
\text { OD prior to inclusion in } \\
\text { the study }\end{array}$ & $\begin{array}{l}1 \mathrm{OD} \\
2 \mathrm{OD} \\
3 \mathrm{OD} \\
4 \mathrm{OD}\end{array}$ & $\begin{array}{c}16 \\
10 \\
4 \\
2\end{array}$ & $\begin{array}{l}0.34 \\
0.59 \\
0.78 \\
0.73\end{array}$ & $\begin{array}{l}0.23-0.52 \\
0.22-1.60 \\
0.25-2.41 \\
0.23-2.36\end{array}$ & 0.05 \\
\hline $\begin{array}{l}\text { Tuberculosis diagnosis } \\
\text { (all participants) }\end{array}$ & $\begin{array}{l}\text { Yes } \\
\text { No }\end{array}$ & $\begin{array}{l}14 \\
65\end{array}$ & $\begin{array}{l}0.55 \\
0.23\end{array}$ & $\begin{array}{l}0.21-1.54 \\
0.17-0.34\end{array}$ & 0.01 \\
\hline $\begin{array}{l}\text { initial ARV } \\
\text { treatment }\end{array}$ & $\begin{array}{l}\text { Monotherapy } \\
\text { HAART }\end{array}$ & $\begin{array}{l}43 \\
15\end{array}$ & $\begin{array}{l}0.25 \\
0.54\end{array}$ & $\begin{array}{l}0.04-0.32 \\
0.04-1.43\end{array}$ & 0.05 \\
\hline
\end{tabular}

$\mathrm{N}=$ number; $\mathrm{CI}=$ confidence interval; $\mathrm{pp} /$ year $=$ per person/year; $\mathrm{P}$ values $\leq 0.05$ were considered statatiscally significant; $\mathrm{ARV}=$ antiretroviral

Table 2

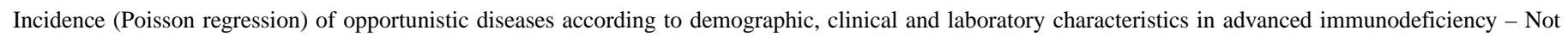
significant variables in the prospective period (after CD4 counts $<100$ cells $/ \mathrm{mm}^{3}$ )

\begin{tabular}{|c|c|c|c|c|c|}
\hline Variable & Category & No. of cases & Incidence of OD pp/year & CI & $P$ value \\
\hline Gender & $\begin{array}{l}\text { Male } \\
\text { Female }\end{array}$ & $\begin{array}{l}57 \\
22\end{array}$ & $\begin{array}{l}0.26 \\
0.38\end{array}$ & $\begin{array}{l}0.18-0.38 \\
0.13-1.05\end{array}$ & 0.26 \\
\hline Age at inclusion & $\begin{array}{l}\leq 40 \text { years } \\
>40 \text { years }\end{array}$ & $\begin{array}{l}42 \\
37\end{array}$ & $\begin{array}{l}0.29 \\
0.29\end{array}$ & $\begin{array}{l}0.19-0.44 \\
0.10-0.82\end{array}$ & 0.95 \\
\hline Aids criteria & $\begin{array}{c}\text { CD4<200 } \\
\text { TB } \\
\text { Protozoan infection } \\
\text { DMAC or CMV } \\
\text { Fungal infection }\end{array}$ & $\begin{array}{c}44 \\
14 \\
9 \\
4 \\
2\end{array}$ & $\begin{array}{l}0.62 \\
0.76 \\
0.54 \\
1.13 \\
2.81\end{array}$ & $\begin{array}{c}0.39-0.97 \\
0.22-2.63 \\
0.14-2.11 \\
0.21-5.99 \\
0.61-12.95\end{array}$ & 0.16 \\
\hline Aids defining OD & $\begin{array}{c}\text { TB } \\
\text { Protozoan infection } \\
\text { DMAC or CMV } \\
\text { Fungal infection }\end{array}$ & $\begin{array}{l}14 \\
9 \\
4 \\
6\end{array}$ & $\begin{array}{l}0.36 \\
0.29 \\
0.61 \\
0.43\end{array}$ & $\begin{array}{l}0.19-0.70 \\
0.05-1.55 \\
0.08-4.30 \\
0.06-2.71\end{array}$ & 0.76 \\
\hline CD4 at entry & $\begin{array}{l}>50 \text { cells } / \mathrm{mm} 3 \\
\leq 50 \text { cells } / \mathrm{mm} 3\end{array}$ & $\begin{array}{l}36 \\
43\end{array}$ & $\begin{array}{l}0.21 \\
0.35\end{array}$ & $\begin{array}{l}0.07-0.58 \\
0.24-0.51\end{array}$ & 0.10 \\
\hline $\begin{array}{l}\text { Restoration of CD } 4 \text { counts } \\
\text { above } 100 \text { cells } / \mathrm{mm}^{3}\end{array}$ & $\begin{array}{l}\text { No } \\
\text { Yes }\end{array}$ & $\begin{array}{l}20 \\
59\end{array}$ & $\begin{array}{l}0.41 \\
0.26\end{array}$ & $\begin{array}{l}0.24-0.73 \\
0.07-0.89\end{array}$ & 0.17 \\
\hline $\begin{array}{l}\text { Restoration of CD } 4 \text { counts } \\
\text { above } 200 \text { cells } / \mathrm{mm}^{3}\end{array}$ & $\begin{array}{l}\text { No } \\
\text { Yes }\end{array}$ & $\begin{array}{l}49 \\
30\end{array}$ & $\begin{array}{l}0.27 \\
0.31\end{array}$ & $\begin{array}{l}0.18-0.42 \\
0.11-0.89\end{array}$ & 0.66 \\
\hline $\begin{array}{l}\text { Sustained viral load } \\
\text { Below 10,000 copies }\end{array}$ & $\begin{array}{l}\text { Yes } \\
\text { No }\end{array}$ & $\begin{array}{l}22 \\
57\end{array}$ & $\begin{array}{l}0.30 \\
0.28\end{array}$ & $\begin{array}{l}0.18-0.51 \\
0.09-0.91\end{array}$ & 0.81 \\
\hline $\begin{array}{l}\text { Sustained viral load } \\
\text { Below 30,000 copies }\end{array}$ & $\begin{array}{l}\text { Yes } \\
\text { No }\end{array}$ & $\begin{array}{l}30 \\
49\end{array}$ & $\begin{array}{l}0.29 \\
0.33\end{array}$ & $\begin{array}{l}0.14-0.40 \\
0.10-1.05\end{array}$ & 0.33 \\
\hline $\begin{array}{l}\text { Sustained viral load } \\
\text { Below 100,000 copies }\end{array}$ & $\begin{array}{l}\text { Yes } \\
\text { No }\end{array}$ & $\begin{array}{l}47 \\
32\end{array}$ & $\begin{array}{l}0.27 \\
0.31\end{array}$ & $\begin{array}{l}0.18-0.42 \\
0.11-0.89\end{array}$ & 0.66 \\
\hline TB diagnosis * & $\begin{array}{l}\text { Yes } \\
\text { No }\end{array}$ & $\begin{array}{l}14 \\
65\end{array}$ & $\begin{array}{l}0.61 \\
0.78\end{array}$ & $\begin{array}{l}0.22-1.67 \\
0.53-1.13\end{array}$ & 0.44 \\
\hline
\end{tabular}

$*$ excluding patients without OD diagnosis; TB = tuberculosis, Protozoan infection = Pneumocystis, CNS toxoplasmosis, Fungal infection = Histoplasma,

Cryptococcus and esophageal Candidosis 
RETROSPECTIVE PERIOD: The incidence rate of ODs in this period was $0.51 \mathrm{pp} / \mathrm{year}(\mathrm{CI}=0.39$ - 0.66). Higher incidence of ODs was observed in individuals whose AIDS diagnosis was established by $\mathrm{OD}$ as compared with diagnosis by $\mathrm{CD} 4^{+}<200$ cells $/ \mathrm{mm}^{3}$, with a value of $\mathrm{p}=0.05$ (Table 3 ).

We determined the incidences of ODs excluding the stratum of patients diagnosed with AIDS by $\mathrm{CD}^{+}$counts, and the results indicate that the difference observed in the first analysis is not repeated $(\mathrm{p}=$ $0.46)$.

OVERALL SURVIVAL: Mean survival of the entire cohort from AIDS diagnosis was 2589 days $(\mathrm{CI}=2363-2816)$ equivalent to 7.09 years, and the median was 2916 days ( 7.98 years).

When $\mathrm{CD}^{+}$count used as an inclusion criterion was categorized into $\leq 50$ cells $/ \mathrm{mm}^{3}(\mathrm{n}=43)$ and $51-100$ cells $/ \mathrm{mm}^{3}(\mathrm{n}=36)$, survival was significantly longer $(\mathrm{p}=0.03)$, for those with $\mathrm{CD} 4^{+}$counts $>50$ cells $/ \mathrm{mm}^{3}$ (mean $=2650$ days, $\mathrm{CI}=2512-2788, \mathrm{HR}=0.13$ ) than for those with $\mathrm{CD}^{+}$counts $\leq 50$ cells $/ \mathrm{mm}^{3}($ mean $=2352, \mathrm{CI}=1956$ 2747).
Survival was also longer for patients whose $\mathrm{CD} 4^{+}$cell counts were restored to $>100 / \mathrm{mm}^{3}$ during follow-up $(\mathrm{n}=59$, mean survival $=2769$ days; $\mathrm{CI}=2583$ - 2955), in comparison with those who did not restore (n $=20$, mean survival $=1911$ days $; \mathrm{CI}=1341-2481, \mathrm{p}=0.03, \mathrm{HR}=0.16$ ).

Modelling survival to incorporate all the significant variables described above revealed that the effect of $\mathrm{CD}^{+}$count at inclusion had become insignificant $(\mathrm{HR}=0.24 ; \mathrm{CI}=0.03-2.01, \mathrm{p}=0.19)$, while the $\mathrm{HR}$ for those with restored $\mathrm{CD} 4^{+}$counts was 0.22 , and significant $(\mathrm{CI}=$ $0.05-0.93, \mathrm{p}$ value $=0.04)$.

We evaluated plasma viral load throughout the study at three cut-off points and observed no differences among the categories evaluated - (a) $<10,000$ copies, mean survival $=2663$ days $(\mathrm{CI}=2261-3064, \mathrm{n}=22)$ and $\geq 10,000$, mean $=2140$ days $(\mathrm{CI}=1939-2348, \mathrm{n}=57)$; (b) < 30,000 , mean $=2635$ days $(\mathrm{CI}=2294-2976, \mathrm{n}=30)$ and $\geq 30,000$, mean $=2136$ days $(\mathrm{CI}=1910-2361)$; and $(\mathrm{c})<100,000,2661$ days $(\mathrm{CI}$ $=2356-2886, \mathrm{n}=32)$ and $\geq 100,000$, mean $=2098(\mathrm{CI}=1777-2418)$.

Other variables were not statistically significant in survival: AIDS diagnosis by immunological criteria, $\mathrm{CD}^{+}<200$ cells $/ \mathrm{mm}^{3}($ mean $=$

Table 3

Incidence (Poisson regression) of opportunistic diseases according to demographic, clinical and laboratory characteristics in advanced immunodeficiency - Significant variables for the retrospective (before CD4 counts dropped $<100$ cells $/ \mathrm{mm}^{3}$ ) period

\begin{tabular}{|c|c|c|c|c|c|}
\hline Variable & Category & $\mathrm{N}$ & Incidence of OD pp/year & $\mathrm{CI}$ & $\mathrm{P}$ value \\
\hline \multirow[t]{5}{*}{ AIDS criteria } & $\mathrm{CD} 4<200$ & 44 & 0.13 & $0.04-0.39$ & 0.05 \\
\hline & $\mathrm{TB}$ & 17 & 0.71 & $0.14-0.39$ & \\
\hline & Protozoan infection & 12 & 0.87 & $0.17-4.45$ & \\
\hline & DMAC or CMV & 11 & 1.70 & $0.24-12.21$ & \\
\hline & Fungal infection & 12 & 1.01 & $0.17-5.87$ & \\
\hline TB diagnosis & Yes & 14 & 0.36 & $0.24-0.54$ & 0.01 \\
\hline (all participants) & No & 65 & 0.76 & $0.29-1.84$ & \\
\hline
\end{tabular}

$\mathrm{N}=$ number of cases; pp/year = per person/year; $\mathrm{CI}=$ Confidence interval; $\mathrm{P}$ values $\leq 0.05$ were considered statatiscally significant; $\mathrm{TB}=\mathrm{Tuberculosis;} \mathrm{Protozoan}$ infection = Pneumocystis; DMAC $=$ disseminated Mycobacterium avium complex; CMV = Cytomegalovirus; Fungal infection $=$ Histoplasmosis, Cryptococcosis and esophageal Candidosis; $\mathrm{CI}=$ confidence interval

Table 4

Incidence (Poisson regression) of opportunistic diseases according to demographic, clinical and laboratory characteristics in advanced immunodeficiency - Not significant variables for the retrospective period (before CD4 counts dropped $<100$ cells $/ \mathrm{mm}^{3}$ )

\begin{tabular}{lcccc}
\hline Variable & Category & No. of cases & Incidence of OD pp/year & CI \\
\hline Aids defining OD & TB & 17 & 0.71 & $0.46-1.08$ \\
& Protozoan infection & 12 & 0.87 & $0.30-2.57$ \\
& DMAC or CMV & 11 & 1.71 & $0.38-7.61$ \\
& Fungal infection & 12 & 1.01 & $0.29-3.51$ \\
TB diagnosis & & & & $0.29-1.87$ \\
$*$ excluding patients & No & 65 & 0.89 & $0.60-1.34$
\end{tabular}


2466 days, $\mathrm{CI}=2086$ - 2847) if compared with diagnosis by OD (mean $=2373$ days, $\mathrm{CI}=2200-2547, \mathrm{p}=0.35)$, prior use of monotherapy (mean $=1276$ days, $\mathrm{CI}=1168-1384)$ compared with the start of treatment with associations of two or three drugs (mean $=2631$ days, CI $=2375$ - 2887), in addition to sex and age at AIDS diagnosis.

SURVIVAL DURING THE PROSPECTIVE PERIOD: We described survival and the factors associated with it from the moment when patients were considered severely immunodepressed, at the point their $\mathrm{CD}^{+}$count fell below 100 cells $/ \mathrm{mm}^{3}$. Overall mean survival was 1376 days $(\mathrm{CI}=1181-1572)$.

Survival was similar among men and women and was neither associated with the age, the AIDS-defining criteria, aggregate diseases prior to inclusion in the study, baseline CD4 counts, viral load or the initial antiretroviral treatment (Table 5).
We found however, longer survival among 59 individuals whose counts were restored to $>100$ cells $/ \mathrm{mm}^{3}$ as compared with those whose counts were not restored (Fig. 1). At the 200-cell cut-off point, however, this effect becomes less evident (Table 5).

The model that included the variables restoration of $\mathrm{CD} 4^{+}$cells with a 100-cell cut-off point and counts at time of inclusion in the study with a 50 -cell $/ \mathrm{mm}^{3}$ cut-off point indicated that restoration of cells $(\mathrm{HR}=0.21$, $\mathrm{CI}=0.05-0.93)$ continued significant $(\mathrm{p}=0.05)$, while count at start of the study $(\mathrm{HR}=0.19, \mathrm{CI}=0.02-1.59)$ lost statistical significance $(\mathrm{p}=$ 0.12 ). The variable determinant of longer survival was restoration of $\mathrm{CD} 4{ }^{+}$count to values $>100$ cells $/ \mathrm{mm}^{3}$.

\section{DISCUSSION}

Our study started at almost the same time as antiretrovirals became

Table 5

Survival according to demographic, clinical and laboratory characteristics in advanced immunodeficiency (after CD4 dropped below 100 cells/mm ${ }^{3}$ prospective period)

\begin{tabular}{|c|c|c|c|c|c|}
\hline Variable & Category & No. of cases & Mean survival & CI & Log rank $p$ value \\
\hline \multirow[t]{2}{*}{ Gender } & Male & 57 & 1424 & $1221-1626$ & 0.57 \\
\hline & Female & 22 & 1023 & $880-1166$ & \\
\hline \multirow[t]{2}{*}{ Age at inclusion } & $\leq 40$ years & 42 & 1074 & $958-1190$ & 0.64 \\
\hline & $>40$ years & 37 & 1417 & $1191-1644$ & \\
\hline \multirow[t]{2}{*}{ Aids criteria } & $\mathrm{CD} 4<200$ & 44 & 1603 & $1495-1711$ & 0.16 \\
\hline & OD & 35 & 1180 & $969-1391$ & \\
\hline Aggregate $\mathrm{N}$ of OD prior & no OD & 47 & 1606 & $1495-1711$ & \\
\hline \multirow[t]{2}{*}{ to inclusion in the study } & 1 and $2 \mathrm{OD}$ & 26 & 1112 & $982-1242$ & 0.11 \\
\hline & 3 and $4 \mathrm{OD}$ & 6 & 966 & $401-1532$ & \\
\hline \multirow[t]{2}{*}{ CD4 at entry } & $>50$ cells $/ \mathrm{mm} 3$ & 36 & 1655 & $1564-1746$ & 0.09 \\
\hline & $\leq 50$ cells $/ \mathrm{mm} 3$ & 43 & 1201 & $1035-1367$ & \\
\hline \multirow{2}{*}{$\begin{array}{l}\text { Restoration of CD } 4 \text { counts } \\
\text { above } 100 \text { cells } / \mathrm{mm}^{3}\end{array}$} & no & 20 & 1489 & $1298-1680$ & 0.01 \\
\hline & yes & 59 & 796 & $683-908$ & \\
\hline \multirow{2}{*}{$\begin{array}{l}\text { Restoration of CD } 4 \text { counts } \\
\text { above } 200 \text { cells } / \mathrm{mm}^{3}\end{array}$} & no & 49 & 1166 & & 0.10 \\
\hline & yes & 30 & 1601 & & \\
\hline Sustained viral load & yes & 22 & 1437 & $1201-1673$ & 0.54 \\
\hline Below 10000 copies & no & 57 & 1018 & $922-1114$ & \\
\hline \multirow{2}{*}{$\begin{array}{l}\text { Sustained viral load } \\
\text { Below } 30000 \text { copies }\end{array}$} & yes & 30 & 1419 & $1193-1645$ & 0.75 \\
\hline & no & 49 & 1022 & $923-1121$ & \\
\hline \multirow{2}{*}{$\begin{array}{l}\text { Sustained viral load } \\
\text { Below } 100000 \text { copies }\end{array}$} & yes & 47 & 0.27 & $0.18-0.42$ & 0.66 \\
\hline & no & 32 & 0.31 & $0.11-0.89$ & \\
\hline \multirow[t]{2}{*}{ Initial ARV treatment } & monotherapy & 43 & 1398 & $1189-1608$ & 0.96 \\
\hline & HAART & 15 & 880 & $824-935$ & \\
\hline
\end{tabular}

$\mathrm{N}=$ number, $\mathrm{CI}=$ Confidence interval, $\mathrm{OD}=$ opportunistic diseases, $\mathrm{ARV}=$ antiretroviral, HAART $=$ higly active antiretroviral therapy 


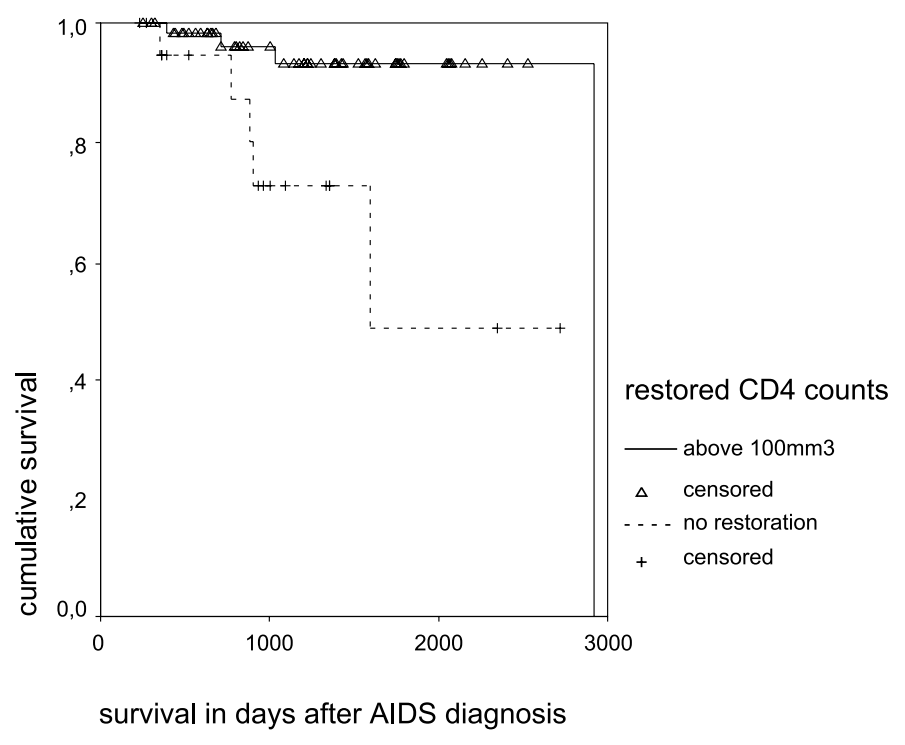

Fig. 1 - Survival (Kaplan Meier) from AIDS diagnosis in patients whose CD4 counts were restored to above 100 cells $/ \mathrm{mm}^{3}$ and those whose counts remained below 100 cells $/ \mathrm{mm}^{3}$

available and as viral load tests were made simultaneously with $\mathrm{CD} 4^{+}$ counts ${ }^{19}$. The results of these measures, such as reduced occurrence of ODs and increased survival, were quickly perceived by the researchers involved in our protocol, as by all health workers responsible for caring for those with HIV/AIDS in Brazil ${ }^{18}$. The same has been observed in other parts of the world ${ }^{5,10,23}$.

When survival from AIDS diagnosis was considered, we found a low death rate, given that the deaths only began to occur following inclusion in the study at a time when the individuals were already at an advanced stage of immunodeficiency, and treated with HAART.

The median survival time for the whole cohort, from AIDS diagnosis up until the end of the study, was 7.09 years. This is an extremely long period when compared with other studies in Brazil, where the period between AIDS diagnosis and death varied from 4.9 months to 9.15 months ${ }^{9,12}$. In another more recent Brazilian study, which differentiated by gender, survival of 20 months was observed for men and 11 months for women ${ }^{26}$. Even studies prior to the introduction of PIs in Europe and the United States encountered post-AIDS survival shorter than our results, viz. Australia, 14.4 months $^{13}$ and 15 months $^{7}$, San Francisco 12.5 months ${ }^{11}$, Denmark 13.0 months ${ }^{24}$ and New York, 13.7 months ${ }^{1}$.

In addition to the effect of HAART, the criteria for inclusion in our study may have led to a selection bias towards individuals who had already survived with AIDS for a reasonably long time before inclusion in our cohort. Also, the $\mathrm{CPqHEC}$ is a centre specializing in research and treatment for individuals with HIV/AIDS, where adhesion to proposed appointments and treatments is good, and where these individuals receive multidisciplinary care and are treated free of charge, not just for HIV, but also for associated ODs.

From 1997 onwards, some authors showed a decline in AIDS-related mortality, which was attributed to antiretroviral therapy with protease inhibitors ${ }^{5,10}$ and longer survival times, thus similar to our results ${ }^{14}$.
In the prospective period of the study (after CD4 counts < 100 cells/ $\left.\mathrm{mm}^{3}\right)$, the incidence rate of opportunistic diseases $(0.29 \mathrm{pp} / \mathrm{y})$ was almost half that observed in the retrospective period (before CD4 counts $<100$ cells $/ \mathrm{mm}^{3}=0.51 \mathrm{pp} / \mathrm{y}$ ), which we consider the opposite of what one might expect on the basis that advanced immunodeficiency should be associated with higher rates. We attribute this finding to the use of HAART during the prospective period. Other authors also describe a decrease in morbidity associated with the use of PIs in several countries ${ }^{10,17,23}$.

Our study showed no significant difference in OD incidence and survival among women and men under or over 40 years old. Although some studies have evaluated the role of age and gender in the prognosis for morbidity and mortality from ODs ${ }^{10,23}$, and no association has been established between these two factors, CHAISSON et al. argues that this finding in other studies reflects differences in access to health services and not in demographic features ${ }^{5}$. One recent study, which evaluated survival among men and women, showed shorter survival times among women that were not explained by differences in access to health services, and pointed to a lower $\mathrm{CD}^{+}$cell counts among women as being the main factor implicated ${ }^{26}$.

In the cases we studied, the AIDS diagnosis by disease was significantly $(\mathrm{p}<0.05)$ associated with greater morbidity from OD in the retrospective period as compared with diagnosis by $\mathrm{CD}^{+}<200$ cells $/ \mathrm{mm}^{3}$. In 1999, LEDERGERBER et al. also showed a risk of disease 2.5 times higher in patients whose AIDS diagnosis was established by $\mathrm{OD}^{10}$. However, survival does not appear to be influenced by these factors in our study, given that these events preceded inclusion in the protocol by several years, and lose force over time.

Although the results presented show a strong relationship between the aggregate quantity of OD during the retrospective period and morbidity during the prospective period, no significant differences in survival was detected.

In the pre-HAART era, some studies suggested that the higher aggregate number of ODs in the course of AIDS was associated with higher risk of death ${ }^{20}$, while others observed that the prognosis for patients with other associated ODs was not necessarily worse than for those with a single disease ${ }^{13}$. More recent studies show that the severity associated with each individual OD continues to influence the prognosis over time ${ }^{10}$, in addition to determining greater risk of incidence of other ODs ${ }^{8}$. However, these studies did not evaluate aggregate OD, because the patients were included in those studies at an early stage of HIV infection and thus without any significant aggregate of OD.

Baseline $\mathrm{CD}^{+}$cell count showed a strong association with survival, which was not shown with morbidity. Many authors have evaluated the role of $\mathrm{CD}^{+}$cell counts in the prognosis of death ${ }^{5,10}$, but few have tested the factors associated with ODs incidence.

The very low incidence of ODs and the small number of participants, as compared with other cohorts in multicentre studies, may have contributed to this association not being detected in our study.

We also evaluated the effect of reconstitution of the immune system by categorizing individuals whose $\mathrm{CD} 4^{+}$cells were or were not restored to levels of $>100$ cells $/ \mathrm{mm}^{3}$, again finding a strong association with 
survival, but not with morbidity. We evaluated restoration of the immune system at another cut-off point $\left(\mathrm{CD}^{+}>200\right.$ cells $\left./ \mathrm{mm}^{3}\right)$ to determine, as other authors have done ${ }^{5}$, whether the effect would be stronger at higher $\mathrm{CD}^{+}{ }^{+}$levels, but observed no statistically significant differences in morbidity at this cut-off point.

No differences were observed in OD rates or in survival according to viral load at the 10,000-copy, 30,000-copy or 100,000-copy cut-off points. Other studies to evaluate the value viral have shown that ODs have been associated with higher viral loads and with progression to other ODs ${ }^{10}$.

In the cases we studied, the use of monotherapy was associated with lower OD rates than triple therapy. Our including individuals with at least one $\mathrm{CD}^{+}$cell count $\leq 100$ cells $/ \mathrm{mm}^{3}$ resulted in a selection bias towards individuals who had survived for a long time with severe immunodeficiency on monotherapy or double therapy. Meanwhile, patients included in our study who initially used triple treatments (15\%) were diagnosed as AIDS cases by disease, already with severe immunodeficiency (CD4 counts below $100 \mathrm{~mm}^{3}$ ) and most of the times with other OD diagnoses which led to an association, at the time of inclusion in the study, between the start of HAART and ODs morbidity.

When we evaluated the effect of these treatments in survival, we observed that although a trend to survive longer was observed among those who used double or triple treatment as the initial regimen, this difference was not statistically significant.

Antiretroviral treatment has been evaluated in other studies, and its protective role has been very clearly demonstrated in studies of large numbers of cases, which noted a relationship between intensification of the treatment (inclusion of PIs) and improved prognosis ${ }^{2,17}$.

In conclusion, our study observed a reduction in OD incidence after CD4 counts dropped below $100 \mathrm{~mm}^{3}$, time almost all patients were under HAART. We also observe the protective role of reconstituting CD4 cells in survival. These effects were associated with the use of highly active antiretroviral treatment jointly with the prophylaxis for OD such as Pneumocystis carinii pneumonia (PCP) neurotoxoplasmosis and tuberculosis which is routine practice at our Centre.

\section{RESUMO}

\section{Morbidade e sobrevida em AIDS avançada no Rio de Janeiro, Brasil}

As doenças oportunistas (DO) são a causa mais comum de morte em pacientes com AIDS. Para acessar a incidência de DO e a sobrevida na imunodeficiência avançada, foram incluídos 79 pacientes com AIDS tratados no Hospital Evandro Chagas (FIOCRUZ) no período de Setembro de 1997 a Dezembro de 1999, com ao menos uma contagem de células CD4 $\leq 100 / \mathrm{mm}^{3}$. A incidência de DO foi analisada pela regressão de Poisson e a sobrevida pela analise de Kaplan Meier e Cox, considerando um período retrospectivo (anterior à contagem de CD4 $\leq$ 100 cels $/ \mathrm{mm}^{3}$ ) e um prospectivo (após a contagem de CD4 $\leq 100$ cels/ $\mathrm{mm}^{3}$ ) e controlando-se características demográficas clínicas e laboratoriais. O intervalo de confiança estipulado foi o de $95 \%$.
O período médio de acompanhamento foi de 733 dias $(\mathrm{IC}=683$ - 782). Durante o estudo, nove $(11,4 \%)$ pacientes morreram. A sobrevida a partir do diagnóstico de AIDS foi em média de 2589 dias (IC = 2363 - 2816) e da data da contagem de CD4 $\leq 100$ cels $/ \mathrm{mm}^{3}$ foi em média de 1376 dias (IC = 1181 - 1572). A incidência de DO foi de $0,51 \mathrm{pp} /$ ano no período pré-CD4 $\leq$ 100 cels $/ \mathrm{mm}^{3}$ e $0,29 \mathrm{pp} /$ ano no período pós-CD4 $\leq 100$ cels $/ \mathrm{mm}^{3}$. Um menor número de DO acumuladas no período pré-CD4 $\leq 100$ cels $/ \mathrm{mm}^{3}$ foi associado com taxas de incidência menores no período pós-CD4 $\leq 100 \mathrm{cels} / \mathrm{mm}^{3}$. O diagnóstico de AIDS baseado em contagem de CD4 ${ }^{+} \leq 200$ cels $/ \mathrm{mm}^{3}$ foi associado com menores taxas de incidência durante o período pós-CD4 $\leq$ 100 cels $/ \mathrm{mm}^{3}$. As contagens basais de células CD4 acima de $50 \mathrm{cel} / \mathrm{mm}^{3}$ $(\mathrm{HR}=0,16)$ foram associadas a um menor risco de morte assim como a restauração da contagem basal acima de 100 cels $/ \mathrm{mm}^{3}(\mathrm{HR}=0,16)$. Controlando-se ambas, somente a restauração da contagem basal manteve sua significância estatística ( $\mathrm{HR}=0,22, \mathrm{p}=0,04)$

Encontramos uma baixa incidência de DO durante o período pósCD4 $\leq 100$ cels $/ \mathrm{mm}^{3}$ e uma sobrevida longa após CD4 $\leq 100$ cels $/ \mathrm{mm}^{3}$. A sobrevida foi significativamente associada com a restauração das contagens de CD4 basais.

\section{ACKNOWLEDGEMENT}

We thank to the Day-Hospital team for the special dedication: Liane Braga da Silveira, Luci Alves, Solange Alves da Cruz, Sonilde Mello Fasolo and Marcia Regina Lyra da Silva.

\section{REFERENCES}

1. BLUM, S.; SINGH, T.; GIBBONS, J. et al. - Trends in survival among persons with acquired immunodeficiency syndrome in New York City: the experience of the first decade of the epidemic. Amer. J. Epidem., 139: 351-361, 1994.

2. BRODT, H.R.; KAMPS B.S.; GUTE, P. et al. - Changing incidence of AIDS-defining illnesses in the era of antiretroviral combination therapy. AIDS, 11: 1731-1738, 1997.

3. CAMERON, W.; HEATH-CHIOSI, M.; KRAVICK, S. et al. - Prolongation of life and prevention of AIDS in advanced immunodeficiency with Ritonavir. In: THIRD CONFERENCE ON RETROVIRUSES AND OPPORTUNISTIC INFECTIONS, Washington, 1996. p. 40.

4. CDC. CENTERS FOR DISEASE CONTROL AND PREVENTION - 1993 revised classification system for HIV infection and expanded surveillance case definition for AIDS among adolescents and adults. MMWR, 4 I (RR-17): 1-19, 1992.

5. CHAISSON, R.E.; KERULY, J.C. \& MOORE, R.D. - Race, sex, drug use, and progression of human immunodeficiency virus disease. New Engl. J. Med., 333: 751-756, 1995.

6. CHAISSON, R.E.; GALLANT, J.E.; KERULY, J.C. \& MOORE, R.D. - Impact of opportunistic disease on survival in patients with HIV infection. AIDS, 12: 29-33, 1998.

7. DORE, G.; HOY, J.F.; MALLAL, S.A. et al. - Trends in incidence of AIDS illnesses in Australia from 1983 to 1994: the Australian cohort. J. AIDS hum. Retrov., 16: 3943, 1997.

8. FINKELSTEIN, D.M.; WILLIAMS, P.L.; MOLENBERGHS, G. et al. - Patterns of opportunistic infections in patients with HIV infection. J. AIDS hum. Retrov., 12: 38-45, 1996.

9. GADELHA, A.M.J. - Casos notificados de AIDS no Município do Rio de Janeiro, 1983-1993: análise de sobrevida. São Paulo, 1987. (Tese de Doutorado Universidade de São Paulo). 
GADELHA, A.J.; ACCACIO, N.; COSTA, R.L.B.; GALHARDO, M.C.; COTRIM, M.R.; DE SOUZA, R.V.; MORGADO, M.; MARZOCHI, K.; LOURENÇO, M.C. \& ROLLA, V.C. Morbidity and survival in advanced AIDS in Rio de Janeiro, Brazil. Rev. Inst. Med. trop. S. Paulo, 44(4):179-186, 2002.

10. LEDERGERBER, B.; EGGER, M. \& TELENTI, A. - AIDS-related opportunistic illness and potent antiretroviral therapy . J. Amer. med. Ass., 283: 2653-2654, 2000.

11. LEMP, G.F; PAYNE, S.F; NEAL, D.; TEMELSO, T. \& RUTHERFORD, G.W. - Survival trends for patients with AIDS. J. Amer. med. Ass., 263: 402-406, 1990.

12. LIMA, D.B. - Validação do sistema de estágios proposto pela Organização Mundial de Saúde para infecção e doença pelo HIV em adolescentes e adultos. Rio de Janeiro, Universidade Federal do Rio de Janeiro, 1992.

13. LUO, K.; LAW, M.; KALDOR, J.M.; MCDONALD, A.M. \& COOPER, D.A. - The role of initial AIDS-defining illness in survival following AIDS. AIDS, 9: 57-63, 1995.

14. McNAGHTEN, A.D.; HANSON, D.L.; JONES, J.L.; DWORKIN, M.S. \& WARD, J.W. - Effects of antiretroviral therapy and opportunistic illness primary chemoprophylaxis on survival after AIDS diagnosis. Adult/Adolescent Spectrum of Disease Group. AIDS, 13: 1687-1695, 1999.

15. MELLORS, J.W.; RINALDO Jr., C.R.; GUPTA, P. et al. - Prognosis in HIV-1 infection predicted by the quantity of virus in plasma. Science, 272: 1167-1170, 1996.

16. MEZZAROMA, I.; CARLESIMO, M.; PINTER, E. et al. - Long-term evaluation of Tcell subsets and T-cell function after HAART in advanced stage HIV-1 disease. AIDS, 13: 1187-1193, 1999.

17. MICHELET, C.; ARVIEUX, C.; FRANÇOIS, C. et al. - Opportunistic infections occurring during highly active antiretroviral treatment. AIDS, 12: 1815-1822, 1998.

18. MINISTÉRIO DA SAÚDE, BRASIL - Programa Nacional de Controle de Doenças Sexualmente Transmissíveis/AIDS. Brasília, Ministério da Saúde, 2000. (www.aids.gov.br).

19. MINISTÉRIO DA SAÚDE, BRASIL - Contagem de células T CD4 ${ }^{+}$e testes de carga viral: principais marcadores laboratoriais para indicação e monitorização do tratamento anti-retroviral. Brasilia, Unidade de Assistência e Unidade de Laboratório da Coordenação Nacional de DST/AIDS, 1998. v. 2000.
20. MOCROFT, A.J.; JOHNSON, M.A.; SABIN, C.A. et al. - Staging system for clinical AIDS patients. Royal Free/Chelsea and Westminster Hospitals Collaborative Group. Lancet, 346: 12-17, 1995.

21. MOUTON, Y.; ALFANDARI, S.; VALETTE, M. et al. - Impact of protease inhibitors on AIDS-defining events and hospitalizations in 10 French AIDS reference centres. Federation National des Centres de Lutte contre le SIDA. AIDS, 11: 101-105, 1997.

22. NORÜIIS, M. - Statistical Program for Social Science. Chicago, SPSS, 1995.

23. PALELLA Jr., F.J.; DELANEY, K.M.; MOORMAN, A.C. et al. - Declining morbidity and mortality among patients with advanced human immunodeficiency virus infection. HIV Outpatient Study Investigators. New Engl. J. Med., 338: 853-860, 1998.

24. PEDERSEN, C.; GERSTOFT, J.; TAURIS, P. et al. - Trends in survival of Danish AIDS patients from 1981 to 1989. AIDS, 4: 1111-1116, 1990.

25. SAAH, A.; HOOVER, D.R.; HE, Y.; KINGSLEY, L. \& PHAIR, J.P. - Factors influencing survival after AIDS: report from the Multicenter AIDS Cohort Study (MACS). J. Acquir. Immune Defic. Syndr., 7: 287-295, 1994.

26. SANTORO-LOPES, G.; HARRISON, L.H.; MOULTON, L.H. et al. - Gender and survival after AIDS in Rio de Janeiro, Brazil. J. AIDS hum. Retrov., 19: 403-407, 1998.

27. SCHECHTER, M.T.; CRAIB, K.J; LE, T.N. et al. - Susceptibility to AIDS progression appears early in HIV infection. AIDS, 4: 185-190, 1990.

28. SERC - Statistics and Epidemiology Research Corporation: EGRET. Seattle, User's Manual, 1985

Received: 5 February 2002

Accepted: 27 June 2002 